\title{
TINDAKAN KEBIRI KIMIA BAGI PELAKU TINDAK PIDANA PERSETUBUHAN DENGAN MENGGUNAKAN KEKERASAN TERHADAP ANAK DI INDONESIA
}

\author{
Atet Sumanto \\ Fakultas Hukum Universitas Wijaya Kusuma Surabaya \\ e-mail: atetsumanto@yahoo.com
}

\begin{abstract}
ABSTRAK
Penelitian ini memaparkan tentang fenomena kasus kejahatan seksual yang pada awal tahun 2016 terjadi di Indonesia, di mana perbuatan pelaku yang melakukan persetubuhan dengan anak (pedofilia) membuat posisi anak semakin terancam, serta mengakibatkan anak mengalami trauma secara fisik dan mental. Penegakan hukum dalam proses peradilan perlu diperkuat agar menimbulkan efek jera bagi pelaku yang melakukan persetubuhan dengan anak (pedofilia). Penguatan penegakan hukum itu dapat dilakukan melalui politik hukum dengan menerapkan tindakan kebiri kimia. Beberapa kasus kejahatan seksual tersebut menyimpulkan bahwa pidana penjara yang dianut dalam Undang-Undang Perlindungan Anak tidak memberikan efek jera, maka perlu menerapkan sanksi baru yang menjadi pidana tambahan dan tindakan yakni dengan penggantian hukuman lama atau penerapan hukum baru melalui kebijakan negara antara legislatif dan eksekutif. Sanksi dalam bentuk penerapan kebiri kimia yang tujuannya untuk menghilangkan nafsu seksual pelaku yang melakukan persetubuhan dengan anak (pedofilia).
\end{abstract}

Kata Kunci: Tindakan Kebiri kimia, Tindak Pidana, kekerasan terhadap anak.

\begin{abstract}
This research explains about the phenomenon of sexual crimes at the beginning of the year 2016 happen in Indonesia, the perpetrator who commits coitus with children (pedophilia) made the position of the child increasingly threatened, as well as resulting in a severely physically and mentally traumatized. So that the rule of law in the judicial process needs to be reinforced in order to pose a deterrent effect for the offender who commits coitus with children (pedophilia). The strengthening of the rule of law can be done through political action by applying the law of chemical castration. Some sexual crime cases concluded that criminal prison adopted in the act of child protection does not give deterrent effect, therefore, need to impose new sanctions and the act replacement or application of new law through the country policy between legislative and executive. The act of this chemical capon directed to reduce sexual crime, especially pedophilia, and handling sexual attack that occurred in Indonesia
\end{abstract}

Keywords: Sexual Crime, Chemical Castration, Crimes.

\section{PENDAHULUAN}

Pada awal tahun 2016 kasus pelecehan seksual pada anak yang dilakukan oleh pelaku pedofilia semakin meningkat. Kasus pelecehan seksual yang menimpa pada anak menjadikan posisi anak semakin terancam akibat dari hasrat seksual yang dilampiaskan kepada anak sebagai sasarannya. Hal ini jelas membuat keberlangsungan dan pertumbuhan anak sebagai korban dari pelecehan seksual menjadi terciderai. Sehingga anak akan mengalami trauma fisik dan mental akibat korban dari kejahatan tersebut.
Ketentuan perundang-undangan yang berlaku di Indonesia telah memberikan perlindungan terhadap anak. Pasal 28b ayat (2) UUD 1945 telah mengatur tentang perlindungan bagi anak di Indonesia, dan secara lebih spesifik juga diatur dalam Pasal 59 ayat (2) huruf $\mathrm{j}$ Undang-Undang No. 35 Tahun 2014 tentang Perubahan atas Undang-Undang No. 23 Tahun 2002 tentang Perlindungan Anak. Dalam peraturan tersebut dijelaskan bahwa anak harus mendapat perlindungan dari segala bentuk kekerasan dan diskriminasi, serta mendapatkan 
perlindungan khusus akibat dari korban kejahatan seksual. Perlindungan terhadap anak ini sangat dibutuhkan agar setiap anak dapat melaksanakan hak dan kewajibannya. ${ }^{1}$ Perlindungan itu juga dibutuhkan agar anak terhindar dari segala bentuk kejahatan, khususnya kejahatan seksual yang dilakukan oleh pedofilia.

Pelaku yang melakukan persetubuhan dengan anak (pedofilia) begitu banyak dan menjamur di Indonesia. Hal itu dapat dibuktikan dengan banyaknya kasus-kasus pelecehan seksual yang terjadi pada anak, seperti kasus yang baru-baru ini terjadi di Kabupaten Rejang Lebong, Bengkulu yang menimpa Yuyun yang dicabuli oleh 14 orang yang sebagian masih berusia di bawah umur secara bergantian dan kemudian setelah dicabuli korban dibunuh. Contoh kasus pelecehan seksual anak yang lain adalah kasus yang terjadi di Bogor yang dilakukan oleh Budiansyah yang mencabuli balita umur 2,5 tahun dan kemudian balita tersebut dibunuh.

Pelaku yang melakukan persetubuhan dengan anak (pedofilia) pada contoh kasus yang sudah dijelaskan di atas, akan mendapat sanksi pidana penjara atas perbuatan pidana yang dilakukannya yakni sesuai Undang-Undang No. 35 Tahun 2014 tentang Perubahan atas Undang-Undang No. 23 Tahun 2002 tentang Perlindungan Anak. Tetapi jika kita melihat dari fakta yang terjadi, pidana penjara saja tidak cukup untuk menjerakan pelaku yang melakukan persetubuhan dengan anak (pedofilia), karena dalam proses peradilan vonis yang diterima oleh seorang pedofilia tergolong masih ringan dan seorang pedofilia juga merupakan orang yang menderita gangguan psikoseksual yang penyembuhannya sangat sulit untuk dilakukan. Dalam politik hukum menjelaskan bahwa hukum digunakan untuk mengekspresikan apa yang terkandung dalam masyarakat dan untuk mencapai apa yang dicitacitakan (ius constituendum). Sehingga penetapan suatu undang-undang adalah sebuah peristiwa historis yang merupakan akibat dari serangkaian fakta yang dapat ditentukan secara kemasyarakatan. ${ }^{2}$

Pemerintah dan DPR telah melakukan revisi terhadap Undang-Undang No. 23 Tahun 2002

\footnotetext{
${ }^{1}$ Maidin Gultom, Perlindungan Hukum Terhadap Anak, Refika Aditama, Bandung, 2013, h. 33.

2 Teguh Prasetyo dan Abdul Halim Barkatullah, Politik Hukum Pidana, Pustaka Pelajar, Yogyakarta, 2005, h. 12-13.
}

tentang Perlindungan Anak. Revisi itu dilakukan melalui Undang-Undang No. 35 Tahun 2014 tentang Perubahan atas Undang-Undang No. 23 Tahun 2002 tentang Perlindungan Anak. Meskipun UndangUndang Perlindungan Anak telah direvisi, sanksi yang dianut dalam Undang-Undang No. 35 Tahun 2014 tersebut masih menggunakan pidana penjara dan memberikan tambahan pidana penjara sepertiga apabila pelaku merupakan orangtua, pengasuh anak, tenaga pendidik, dan lain-lain. Sehingga membuat Komisi Perlindungan Anak Indonesia (selanjutnya disebut KPAI) dan pihak terkait lainnya memunculkan suatu wacana untuk menambahkan sanksi kebiri kimia untuk dapat membuat efek jera yang sebenarnya bagi pedofilia.

Mengingat daruratnya negara Indonesia akan kejahatan seksual terhadap anak, akhirnya Pemerintah mengesahkan Undang-Undang No. 17 Tahun 2016 tentang Peraturan Pemerintah Pengganti UndangUndang No. 1 Tahun 2016 tentang Perubahan Kedua atas Undang-Undang No. 23 Tahun 2002 tentang Perlindungan Anak menjadi Undang-Undang. Di mana Undang-undang No. 17 Tahun 2016 tersebut merupakan amandemen kedua dari Undang-Undang Perlindungan anak sebelumnya (UU No. 23 Tahun 2002 Jo. UU No. 35 Tahun 2014).

Dalam Undang-Undang No. 17 Tahun 2016 tersebut mengatur lebih luas lagi dalam pemberatan sanksi pidana bagi pelaku yang melakukan persetubuhan dengan anak (pedofilia). Di mana salah satu pemberatan sanksi pidana adalah hukuman kebiri kimiawi. Kebiri kimia ini juga sudah banyak diterapkan di berbagai negara. Kebiri kimia ini merupakan suntikan kimia (chemical emasculated) yang berfungsi menghilangkan hormon seksual pada pedofilia yang menjadi faktor terpenting untuk menimbulkan gairah seksual.

\section{PERUMUSAN MASALAH}

Kondisi tersebut kemudian menarik untuk dikaji lebih lanjut. Oleh sebab itu, artikel ini akan mengkaji mengenai; bagaimana pengaturan sanksi pidana bagi pelaku tindak pidana yang melakukan persetubuhan dengan anak (pedofilia) menggunakan kekerasan anak ditinjau dari hukum positif yang berlaku saat ini? dan apakah tindakan pengebirian kimia bagi pelaku yang diatur dalam Undang-Undang Perlindungan Anak dapat diberlakukan secara efektif? 


\section{METODE PENELITIAN}

Metode yang digunakan dalam penelitian ini adalah penelitian hukum normatif yang menganalisa tentang penerapan hukum berdasarkan peraturan perundang-undangan yang berlaku pada pengalaman yang terjadi di masyarakat, serta dalam proses penegakan hukum. Penelitian hukum normatif ini menggunakan pendekatan peraturan perundangundangan (statute approach), serta pendekatan kasus (case approach). ${ }^{3}$

\section{PEMBAHASAN}

\section{Ketentuan Hukum Terkait Pidana Persetubuhan dengan Anak Menggunakan Kekerasan}

Pelaku yang melakukan persetubuhan dengan anak yang menggunakan kekerasan atau biasa dikenal dengan istilah Pedofilia berasal dari bahasa Yunani yakni paedo (anak) dan philia (cinta). Secara harafiah pedofilia berarti cinta pada anakanak. Akan tetapi terjadi perkembangan, sehingga secara umum digunakan sebagai istilah untuk menerangkan salah satu kelainan perkembangan psikoseksual dimana individu memiliki hasrat erotis yang abnormal terhadap anak-anak. ${ }^{4}$ Pedofilia juga dapat dikategorikan menjadi empat kategori, yakni: pedofilia tipe ekslusif, pedofilia tipe non-ekslusif, same sex pedofilia, dan cross sex pedofilia.

Gangguan psikoseksual pada seorang pedofilia dapat dibagi dalam dua jenis; pertama, pedofilia hormonal, yang merupakan kelainan biologis dan bawaan seseorang sejak lahir. Dan kedua, pedofilia habitual, kelainan seksual yang terbentuk dari kondisi sosial penderitanya. ${ }^{5}$ Perbuatan pedofilia itu juga menandakan ketidakmampuan berhubungan seksual dengan sesama dewasa. ${ }^{6}$ Sehingga dari penjelasan di atas dapat dipahami bahwa upaya penyembuhan pada pedofilia sangat sulit untuk dilakukan akibat dari kebutuhan seksual yang tidak bisa dicegah dan dihentikan.

\footnotetext{
${ }^{3}$ Peter Mahmud Marzuki, Penelitian Hukum Edisi Revisi, Kencana Prenada Media Group, Jakarta, 2014, h. 133-136.

4 Sawatri Supardi, Bunga Rampai Kasus Gangguan Psikoseksual, Refika Aditama, Bandung, 2005, h. 71.

${ }^{5}$ Muhammad Zainuddin, "Kebijakan Hukum Pidana Dalam Rangka Penanggulangan Kejahatan Pedofilia”, Tesis, Fakultas Hukum Universitas Diponegoro, Semarang, 2007, h. 17.

6 Indra Irma Wahyuni, "Pedofilia Ditinjau dari Pertanggungjawaban Pidana”, Skripsi, Fakultas Hukum Universitas Wijaya Kusuma Surabaya, Surabaya, 2011, h. 7.
}

Pengaturan bagi pelaku yang melakukan persetubuhan dengan anak (pedofilia) telah diatur dalam peraturan perundang-undangan Indonesia yakni dalam Kitab Undang-Undang Hukum Pidana (selanjutnya disebut KUHP) dan Undang-Undang No. 35 Tahun 2014 tentang Perubahan atas UndangUndang No. 23 Tahun 2002 tentang Perlindungan Anak. Tetapi rumusan pasal-pasal KUHP maupun yang ada dalam Undang-Undang No. 35 Tahun 2014 untuk saat ini belum menjelaskan secara eksplisit tentang pedofilia itu sendiri. Mengingat korban dari pelaku yang melakukan persetubuhan dengan anak (pedofilia) ini banyak menimpa pada anak dan berkaitan dengan kepatutan bertingkah laku dalam bidang seksual, ${ }^{7}$ maka rezim KUHP dan UndangUndang Perlindungan Anak hanya mengatur tentang kejahatan terhadap kesusilaan. Jadi sepanjang unsurunsur baik dalam ketentuan KUHP maupun UndangUndang Perlindungan Anak terpenuhi, maka pelaku pedofilia tetap dapat di pidana sesuai ketentuan yang berlaku tersebut.

Banyak pertanyaan yang timbul terkait istilah pedofilia yang melakukan persetubuhan terhadap anak, apakah dapat dikategorikan sebagai orang yang mempunyai gangguan kejiwaan sesuai rumusan dalam Pasal 44 KUHP atau tidak. Pada dasarnya pertanyaan tersebut dapat dijawab oleh ahli yakni seorang psikiater yang dapat menentukan bahwa pelaku yang melakukan persetubuhan dengan anak (pedofilia) dapat dikategorikan sebagai seorang yang terganggu jiwanya atau tidak berdasarkan pemeriksaan dan analisisnya. Menurut kategorinya, pedofilia merupakan suatu penyakit akibat gangguan psikoseksual, jadi secara umum seorang pelaku yang melakukan persetubuhan dengan anak (pedofilia) tidak dapat dinyatakan sebagai seorang yang menderita gangguan jiwa sampai ada keputusan psikiater yang menyatakan bahwa seorang pelaku yang melakukan persetubuhan dengan anak (pedofilia) mempunyai gangguan kejiwaan. Pada faktanya seorang pelaku yang melakukan persetubuhan dengan anak (pedofilia) secara aktif dan sengaja mampu melakukan aktifitas seksual terhadap anak-anak yang menjadi korbannya, sehingga ia tetap dianggap sebagai orang yang mampu bertanggungjawab secara hukum atau criminal responsibilty.

\footnotetext{
${ }^{7}$ Muhammad Zainuddin, Loc.Cit., h. 23-24.
} 
Pengaturan hukum di Indonesia bagi pelaku yang melakukan persetubuhan dengan anak (pedofilia) yang melakukan perbuatan persetubuhan atau pencabulan telah diatur dalam KUHP Pasal 290 angka 2 dan angka 3 KUHP. Pasal 290 angka 2 di atas dapat dijelaskan bahwa perbuatan cabul tersebut merupakan perbuatan cabul dalam pengertian yang umum yang bisa dilakukan terhadap pria maupun wanita. ${ }^{8}$ Sedangkan Pasal 290 angka 3 selain perbuatan cabul juga bisa terjadi karena persetubuhan. Akan tetapi ancaman pidana dalam Pasal 290 KUHP begitu rendah, Pasal 290 KUHP hanya mengancam dengan ancaman pidana maksimal 7 tahun penjara.

Pasal 290 angka 2 dan angka 3 KUHP yang telah dijelaskan di atas merupakan aturan umum yang mengatur perbuatan yang dilakukan oleh pelaku yang melakukan persetubuhan dengan anak (pedofilia) baik perbuatan cabul atau persetubuhan. Mengingat ada asas lex specialis derogat legi generali, maka ketentuan dalam Pasal 290 angka 2 dan angka 3 KUHP menjadi dikesampingkan. Hal itu dikarenakan telah ada aturan khusus yang diatur dalam Undang-Undang Perlindungan Anak yang terbaru yakni Undang-Undang No. 17 Tahun 2016 tentang Peraturan Pemerintah Pengganti UndangUndang No. 1 Tahun 2016 tentang Perubahan Kedua atas Undang-Undang No. 23 Tahun 2002 tentang Perlindungan Anak Menjadi Undang-Undang.

Undang-Undang No. 17 Tahun 2016 tersebut merupakan revisi kedua atas Perubahan UndangUndang Perlindungan Anak yang lama (UU No. 23 Tahun 2002 Jo. UU No. 35 Tahun 2014). Pengaturan khusus (lex specialis) dalam Undang-Undang No. 17 Tahun 2016 telah diatur di dalam Pasal 81 dan Pasal 82 Peraturan Pemerintah Pengganti Undang-Undang No. 1 Tahun 2016 tentang Perubahan Kedua atas UndangUndang No. 23 Tahun 2002 tentang Perlindungan Anak Menjadi Undang-Undang (Selanjutnya disebut PERPPU No. 1 Tahun 2016). Pasal 81 PERPPU No. 1 Tahun 2016 menjelaskan tentang pelaku pelaku yang melakukan persetubuhan dengan anak (pedofilia) yang melakukan persetubuhan dengan anak, sedangkan Pasal 82 PERPPU No. 1 Tahun 2016 menjelaskan tentang pelaku yang melakukan pencabulan terhadap anak (pedofilia) yang keduanya

${ }^{8}$ Tongat, Hukum Pidana Materiil, Djambatan, Jakarta, 2003, h. 139 dapat dilakukan dengan cara tipu muslihat, rangkaian kebohongan, dan lain-lain.

Sanksi pasal dalam Pasal 81 dan 82 PERPPU No. 1 Tahun 2016 sebagaimana telah ditetapkan menjadi Undang-Undang No. 17 Tahun 2016 telah mengatur secara komperhensif yakni pidana penjara paling singkat 5 tahun serta paling lama 15 tahun penjara dan denda paling banyak Rp. 5.000.000.000,- (lima milyar rupiah). Selain itu kedua pasal tersebut juga memberikan ayat tambahan apabila pelaku tindak pidananya dilakukan oleh orangtua, wali, pengasuh anak, pendidik, atau tenaga kependidikan, serta seorang residivis, maka ancaman pidana penjaranya ditambah sepertiga.

Bahwa selain pidana penjara, PERPPU No. 1 Tahun 2016 sebagaimana telah ditetapkan menjadi Undang-Undang No. 17 Tahun 2016 tersebut juga telah memberikan pengaturan pemberatan pidana (bentuk kualifisier) bagi pelaku pelaku yang melakukan persetubuhan dengan anak (pedofilia) yakni pidana mati, pidana seumur hidup, pidana paling singkat 10 tahun dan pidana paling lama 20 tahun bagi pelaku pelaku yang melakukan persetubuhan dengan anak (pedofilia) yang menimbulkan korban lebih dari 1 (satu) orang, mengakibatkan luka berat, gangguan jiwa, penyakit menular, terganggu fungsi reproduksi, dan/atau meninggal dunia.

Dalam PERPPU No. 1 Tahun 2016 sebagaimana telah ditetapkan menjadi Undang-Undang No. 17 Tahun 2016 juga telah menampung sanksi yang selama ini selalu didengung-dengungkan oleh masyarakat dan pihak-pihak terkait lainnya yakni penerapan kebiri kimia. Kebiri kimia ini telah di atur dalam Pasal 81 ayat (7) PERPPU No. 1 Tahun 2016 sebagaimana telah ditetapkan menjadi UndangUndang No. 17 Tahun 2016. Di mana pelaksanaan tindakan kebiri kimia ini akan diberikan paling lama 2 tahun dan dilaksanakan setelah terpidana atau pelaku pelaku yang melakukan persetubuhan dengan anak (pedofilia) menjalani pidana pokoknya atau saat terpidana menjalani masa rehabilitasi, serta ditambah pemasangan alat pendeteksi elektronik sebagai bentuk kontrol terhadap perilaku terpidana atau pelaku yang melakukan persetubuhan dengan anak (pedofilia) ketika kembali di masyarakat. Tindakan kebiri kimia dan pemasangan alat pendeteksi elektronik dilakukan apabila terpidana atau pelaku yang melakukan persetubuhan dengan anak (pedofilia) terbukti 
melanggar Pasal 81 ayat (4) atau ayat (5) PERPPU No. 1 Tahun 2016 sebagaimana telah ditetapkan menjadi Undang-Undang No. 17 Tahun 2016 yakni sebagai residivis atau menimbulkan korban lebih dari 1 (satu) orang, mengakibatkan luka berat, gangguan jiwa, penyakit menular, terganggu fungsi reproduksi, dan/atau meninggal dunia.

Selain kebiri kimia, terpidana atau pelaku pedofilia juga dapat dikenai pidana tambahan berupa pengumuman identitas pelaku sebagai bentuk sanksi sosial di masyarakat apabila terpidana atau pelaku yang melakukan persetubuhan dengan anak (pedofilia) melanggar Pasal 81 ayat (1), (3), (4), dan (5) PERPPU No. 1 Tahun 2016 sebagaimana telah ditetapkan menjadi Undang-Undang No. 17 Tahun 2016 yakni melakukan persetubuhan, pelaku tindak pidananya dilakukan oleh orangtua, wali, pengasuh anak, pendidik, atau tenaga kependidikan, serta seorang residivis, atau dapat pula menimbulkan korban lebih dari 1 (satu) orang, mengakibatkan luka berat, gangguan jiwa, penyakit menular, terganggu fungsi reproduksi, dan/atau meninggal dunia.

Sedangkan Pasal 82 PERPPU No. 1 Tahun 2016 sebagaimana telah ditetapkan menjadi UndangUndang No. 17 Tahun 2016 hanya memberikan pidana tambahan berupa pengumuman identitas pelaku bagi terpidana yang melanggar Pasal 82 ayat (1-4) PERPPU No. 1 Tahun 2016 sebagaimana telah ditetapkan menjadi Undang-Undang No. 17 Tahun 2016 yakni yang melakukan percabulan, pelaku tindak pidananya dilakukan oleh orangtua, wali, pengasuh anak, pendidik, atau tenaga kependidikan, serta seorang residivis, atau dapat pula menimbulkan korban lebih dari 1 (satu) orang, mengakibatkan luka berat, gangguan jiwa, penyakit menular, terganggu fungsi reproduksi, dan/atau meninggal dunia. Dan dapat pula dikenai tindakan rehabilitasi dan pemasangan alat pendeteksi elektronik apabila melanggar Pasal 82 ayat (2-4) PERPPU No. 1 Tahun 2016 sebagaimana telah ditetapkan menjadi Undang-Undang No. 17 Tahun 2016 yakni pelaku tindak pidananya dilakukan oleh orangtua, wali, pengasuh anak, pendidik, atau tenaga kependidikan, serta seorang residivis, atau dapat pula menimbulkan korban lebih dari 1 (satu) orang, mengakibatkan luka berat, gangguan jiwa, penyakit menular, terganggu fungsi reproduksi, dan/atau meninggal dunia.
Akan tetapi pidana tambahan dan/atau tindakan baru bisa di eksekusi apabila telah diputus bersamaan dengan pidana pokoknya. Serta pidana tambahan dan tindakan tidak diberlakukan apabila pelaku tindak pidananya adalah anak.

Kebiri kimia telah diterapkan di beberapa negara dan penerapan kebiri kimia itu terbukti efektif dalam proses penegakan hukum. Beberapa negara yang telah menerapkan kebiri kimia adalah salah satunya negara bagian California, Amerika Serikat. Negara bagian California, Amerika Serikat sejak tahun 1996 telah menerapkan sanksi kebiri kimia yang diberlakukan untuk pelaku kejahatan seksual. Pada waktu itu memang banyak anak-anak yang menjadi korban dari pelaku pedofilia. Suatu studi menunjukkan bahwa 20\% (duapuluh persen) dari semua perempuan dan $10 \%$ (sepuluh persen) dari semua laki-laki telah dilecehkan sebelum usia 18 (delapan belas) tahun. ${ }^{9}$

Pada tahun 1991 Badan Statistik Keadilan California mendata bahwa 43.000 tahanan nasional dipenjara karena pelanggaran seksual terhadap anak-anak. Maraknya kasus-kasus pedofilia yang terjadi di California, Amerika Serikat, membuat Pemerintahan California saat itu mengusulkan untuk menerapkan kebiri kimia bagi pelaku pedofilia agar pelaku pedofilia benar-benar jera dan tidak menjadi residivis. Karena selama 10 tahun terakhir saat itu, penyelesaian kasus-kasus pedofilia lebih menekankan sanksi pada aspek hukum pidana yang didasarkan pada unsur melawan hukum, yakni suatu perbuatan yang dilakukan oleh pembuat tindak pidana sebagai pelaku langsung yang telah dinyatakan melanggar ketentuan hukum atau rumusan delik sebagaimana yang telah dirumuskan dalam peraturan pidana. Sehingga dari hal itu, banyak organisasi kesehatan di California serta lembaga legislatif California menganjurkan pendekatan yang lebih komperhensif dalam menangani kasus pedofilia yakni terkait dengan penerapan kebiri kimia. Mereka berpendapat bahwa kebiri kimia itu memang sangat membantu dalam proses penegakan hukum untuk diberikan pada pelaku pedofilia agar dapat membuat jera dan menghilangkan gairah seksual, serta memberikan

\footnotetext{
${ }^{9}$ Audrey Moog, 1999, "California Penal Code Section 645: Legislators Practice Medicine on Child Molesters", Journal Contemporary Health Law \& Policy, Volume 15 Issue 2 Article 13, h. 712 .
} 
jaminan perlindungan terhadap anak dari ancaman pedofilia.

Tanggal 17 April 1996, Gubernur California yang kala itu dijabat oleh Pete Wilson menandatangani dan mengesahkan undang-undang nasional pertama tentang pengebirian kimia bagi pelaku kejahatan seksual yang dituangkan dalam KUHP California. Dimana KUHP California menjelaskan bahwa hukum memberi kewenangan pengadilan untuk menjatuhkan pengebirian kimia (chemical emasculated) yang di Amerika dikenal sebagai kebiri kimia medroxyprogesterone asetat (MPA). ${ }^{10}$ Kebiri kimia dengan medroxyprogesterone asetat (yang selanjutnya disebut MPA) telah dipelajari di Amerika sejak tahun 1960, para medis yang mempelajari MPA itu mengidentifikasi dan menjelaskan bahwa MPA merupakan pengobatan yang paling menjanjikan dan dinilai efektif untuk diterapkan pada pelaku kejahatan seksual dibandingkan perawatan dan pengobatan lainnya.

Istilah MPA lebih cocok digunakan sebagai kebiri kimia, karena MPA merupakan istilah kimia dalam bidang medis. Istilah tersebut mengacu pada penggunaan antiandrogen, yang merupakan hormon sintetis yang menurunkan produksi hormon pada tubuh untuk pengobatan gangguan seksual tertentu. Pemerintahan California juga menegaskan bahwa pengebirian kimia di atas tidak dikonotasikan sebagai tindakan bedah atau mutilasi organ tubuh, melainkan suntikan kimia ke tubuh dengan menggunakan pemanfaatan dalam bidang medis yakni dengan menggunakan MPA. Keberhasilan penerapan MPA bagi pelaku pedofilia didukung oleh sebuah studi yang dilakukan oleh The Johns Hopkins University's National Institute yang menunjukkan bahwa dalam proses penegakan hukum, 20 orang pedofilia yang dilakukan pengebirian kimia, hanya 3 yang menjadi residivis. Hal ini membuktikan bahwa 17 orang yang telah dilakukan pengebirian kimia tidak menjadi residivis. Kebiri kimia itu juga menunjukkan keefektifan dalam membuat jera pedofilia, ${ }^{11}$ dan sekaligus telah mencerminkan nilai kemanfaatan.

Negara bagian California baru memberlakukan kebiri kimia bagi pelaku pedofilia setelah pelaku mendapatkan pembebasan bersyarat atau hukuman percobaan sesuai pemeriksaan dari psikiater serta

\footnotetext{
${ }^{10}$ Audrey Moog, Loc.Cit., h. 711.

${ }^{11}$ Audrey Moog, Loc. Cit., h. 720.
}

dengan didukung penetapan dari pengadilan. Kebiri kimia tersebut dapat dilaksanakan ke tubuh pelaku pedofilia dengan suntikan MPA melalui bantuan dari Departemen Kesehatan dan juga disesuaikan dengan kondisi pelaku pedofilia untuk menentukan dosis suntikannya. Pengebirian kimia juga masih bisa dikecualikan dan dihentikan apabila Departemen Kesehatan serta Departemen Koreksi dan Rehabilitasi serta psikiater berkoordinasi dan menyatakan bahwa kebiri kimia sudah tidak diperlukan lagi bagi pedofilia, meskipun pelaku pedofilia masih menjalani pembebasan bersyarat atau hukuman percobaan.

Setelah kebiri kimia dengan MPA diterapkan di Negara Bagian California, Amerika Serikat, sebuah studi menunjukkan bahwa sekitar 85\% (delapan puluh lima persen) pelaku pedofilia tidak menjadi residivis. ${ }^{12}$ Penerapan kebiri kimia tersebut memberikan peran dan kontribusi dalam membantu proses penegakan hukum, terbukti kebiri kimia sukses untuk membuat pedofilia jera serta mencegah kambuhnya gangguan psikoseksual yang diderita pedofilia.

Pengaturan tentang pengebirian kimia MPA diatur dalam bagian 645 KUHP California. Bagian 645 KUHP California merupakan ketentuan pengebirian kimia bagi pelaku pedofilia yang melakukan pelecehan seksual baik di sengaja atau lalai. Sedangkan bagian 645 KUHP California subdivisi c ayat (1-4) dapat dijelaskan tentang perbuatan pidana seorang pedofilia yang dapat dibagi menjadi 4 bagian yakni; sodomi, perbuatan cabul, senggama mulut atau oral seks, dan penetrasi seksual. MPA yang digunakan oleh Pemerintah California untuk menerapkannya pada pelaku pedofilia yang diatur dalam bagian 645 KUHP California semakin menegaskan bahwa Pemerintah California sangat menjamin perlindungan terhadap anak yang merupakan sasaran bagi pelaku kejahatan seksual. Selain itu, Pemerintah California juga mempunyai sistem hukum yang sangat komprehensif, hal itu terbukti melalui pencangkokan hukum antara pemanfaatan bidang medis yang dileburkan ke dalam KUHP California. Jadi selain pidana penjara yang dijalani dijatuhkan sesuai dengan konsep dari pemidanaan, juga harus ditambah sanksi kebiri kimia yang berfungsi menghilangkan gairah seksual pada hormon seksualnya.

\footnotetext{
${ }^{12}$ Audrey Moog, Ibid.
} 
Kebiri kimia dengan MPA yang dinilai efektif tersebut bukan merupakan sebuah jaminan yang permanen untuk penanganan kasus-kasus pedofilia di masa yang akan datang, karena modus operandi dan cara pelaku pedofilia selalu berkembang untuk mematahkan kebiri kimia yang diterapkan saat ini. Tetapi dengan adanya kebiri kimia MPA yang diterapkan saat ini, setidaknya dapat menekan dan mengurangi pelecehan seksual pada anak dan yang paling penting dapat membuat jera pelaku pedofilia.

Kebiri kimia dengan MPA yang diatur dalam Bagian 645 KUHP California merupakan solusi yang tepat bagi penanganan dan penyelesaian hukum bagi pelaku pedofilia. Karena Bagian 645 KUHP California juga berfungsi sebagai alat hukum lain untuk memberikan pengobatan dan terapi bagi pelaku pedofilia di samping menjalani masa pidananya.

\section{Efektivitas Tindakan Kebiri Kimia Bagi Pelaku Persetubuhan dengan Anak Menggunakan Kekerasan}

Dari contoh penerapan tindakan kebiri kimia di negara bagian California Amerika Serikat, sebagaimana telah dijelaskan di atas. Terbukti kebiri kimia memang efektif dalam memberikan efek jera bagi pelaku yang melakukan persetubuhan dengan anak (pedofilia). Akan tetapi di Indonesia sendiri sejak pertama kali PERPPU No. 1 Tahun 2016 diterbitkan, terkait tindakan kebiri kimia ini sampai saat ini masih banyak menuai kontroversi, khususnya untuk eksekutor dalam pelaksanaan suntikan kimianya. Karena dalam proses tindakan kebiri kimia tersebut juga harus melibatkan profesi kedokteran dalam bidang medis. Ikatan Dokter Indonesia (IDI) juga telah mengeluarkan statement tidak bersedia untuk melaksanakan eksekusi tindakan kebiri kimia. IDI juga menghimbau kepada anggotanya untuk tidak menjalankan proses tindakan kebiri kimia terhadap seorang pedofilia, sekalipun itu perintah undang-undang. Karena menurut Ketua Ikatan Dokter Indonesia (IDI), Prof. Ilham Oetama Marsis, proses tindakan kebiri kimia tersebut merupakan suatu perbuatan yang merusak organ manusia, dan itu jelas bertentangan dengan sumpah dokter dan merupakan sebuah pelanggaran etika di bidang medis. Lebih lanjut Ketua IDI menjelaskan bahwa profesi dokter merupakan sebuah profesi yang membantu untuk mengupayakan kesembuhan bagi para pasiennya dan bukan untuk merusaknya.

Pendapat yang sama juga diutarakan Ketua Perhimpunan Dokter Spesialis Andrologi, Prof. Wimpie Pangkahila, yang menjelaskan bahwa tindakan kebiri kimia juga menimbulkan efek seperti serangan jantung, osteoporosis, dan kerusakan kognitif otak. Proses pengebirian kimia sudah pasti jelas akan menurunkan hormon testosteron yang berimplikasi nafsu seksual tersebut akan hilang. Ia juga berpendapat apabila pedofilia ini di kebiri secara kimia setelah menjalani pidana pokok penjara, pelaku yang melakukan persetubuhan dengan anak (pedofilia) juga akan mencari celah untuk membangkitkan nafsu seksualnya kembali yakni dengan datang ke dokter untuk minta disuntik agar nafsu seksual kembali bangkit. Pendapat berbeda justru disampaikan oleh Psikiater dr. Hubertus Kasan. Ia menjelaskan bahwa kebiri kimia yang merupakan bentuk penyiksaan ini perlu diluruskan. Menurutnya kebiri kimia ini merupakan sebuah terapi bagi seseorang yang dianggap menderita kelainan seksual (pedofilia). Karena terapi ini justru dianggapnya sebagai alternatif pengobatan yang efektif, terbukti negara-negara yang memberlakukan kebiri kimia ini berhasil menurunkan residivis pedofilia atau kasus kejahatan seksual yang terjadi.

Terlepas dari segala perdebatan yang terjadi di atas, terutama dari segi kewenangan eksekutor kebiri kimia terhadap pelaku pedofilia juga masih menjadi kontroversi. Namun pemerintah mencoba untuk mengatasi perdebatan ini dengan mencoba akan memanggil organisasi IDI, sekaligus untuk duduk bersama membahas terkait dengan eksekusi pelaksanaan kebiri kimia. Pembahasan tersebut bertujuan untuk memberikan penjelasan kepada IDI dan meminta pendapat IDI tentang bagaimana proses pelaksanaan tindakan kebiri kimia itu dilakukan.

Berbagai pendapat juga muncul dari perspektif Hukum Islam dan Hak Asasi Manusia. Dari perspektif Hukum Islam sendiri juga muncul pendapat yang berbeda pula. Hal itu dijelaskan oleh K.H. Ovied, Wakil Ketua Dewan Fatwa Pengurus Besar Al Jam iyatul Washliyah (PB. Al Washliyah). K.H. Ovied menyambut positif dikeluarkannya PERPPU No. 1 Tahun 2016 yang kini telah ditetapkan menjadi Undang-Undang No. 17 Tahun 2016. Menurutnya, sanksi hukum kebiri tersebut telah sejalan dengan 
hukum Islam, "Hukum Islam terhadap pemerkosa disertai pembunuhan adalah hukum mati”. Dalam AlQur`an secara tegas dan jelas menyatakan mengenai dibolehkannya hukum mati termasuk kebiri terhadap pembunuh, pemerkosa. Bahkan lebih dari kebiri, AlQur`an membolehkan seperti potong tangan dan kaki. Hal itu sebagaimana termaktub dalam Firman Allah SWT Surah Al-Maidah ayat 33. Ulama yang setuju dengan hukuman kebiri ini lebih mengedepankan aspek maslahat ketika hukum kebiri diterapkan.

Ketua Komisi Dakwah dan Pengembangan Masyarakat Majelis Ulama Indonesia (MUI), K.H. Cholil Nafis, berpendapat pula bahwa pemberian hukuman kebiri pada terpidana pedofilia bisa memberikan efek jera (zawajir). Hakim bisa berijtihad dalam memberikan hukuman dalam kasus ini dengan pertimbangan zawajir tadi.

Selain mereka yang pro terhadap kebiri kimia ini, mereka yang kontra soal hukuman kebiri ini juga berasal dari kalangan kontemporer, seperti Majelis Tarjih dan Tajdid PP. Muhammadiyah, Asosiasi Pondok Pesantren Jawa Timur, Hizbut Tahrir, serta kalangan ulama kontemporer lainnya. Mereka berdalil, kebiri berarti mengubah fisik manusia, melanggar HAM, dan melahirkan jenis hukum baru yang tak pernah dikenal dalam konsep jinayah Islamiyah.

Dari perspektif HAM sendiri, mereka berdalil bahwa proses pengebirian kimiawi tersebut merupakan tindakan penyiksaan fisik dan mengurangi fungsi organ manusia, dan hal itu jelas merupakan sebuah bentuk pelanggaran HAM. Menurut Komisioner Komnas HAM Natalius Pigai, Hak hidup seseorang tidak boleh dikurangi atau dibatasi oleh undang-undang. Bahkan ia mengatakan alasan tersebut bukan semata-mata pro terhadap pelaku yang melakukan persetubuhan dengan anak (pedofilia), tetapi lebih menekankan aspek kemanusiaan dalam hak asasi manusia. Ia juga tetap memberikan empati pada korban yang menjadi sasaran pelaku pedofilia.

Beberapa pakar hukum juga berpendapat pula bahwa PERPPU No. 1 Tahun 2016 sebagaimana telah ditetapkan menjadi Undang-Undang No. 17 Tahun 2016 ini lahir merupakan suatu sikap reaktif pemerintah, tanpa melakukan telaah atau kajian yang komperhensif. Seharusnya pemerintah kita sebelum membuat kebijakan harus melakukan kajian atau telaah yang lebih mendalam, sehingga suatu aturan ketika diterbitkan akan benar-benar memenuhi segala aspek baik secara filosofis, historis, sosiologis, dan yuridis.

Perbuatan yang dilakukan oleh pelaku yang melakukan persetubuhan dengan anak (pedofilia) juga merupakan suatu bentuk dari pelanggaran hukum yang dapat dilihat dari beberapa kajian perspektif psikologi hukum, psikologi kriminal dan teori-teori dalam sosiologi hukum. Dari perspektif psikologi hukum dapat dijelaskan bahwa perilaku melanggar hukum yang dilakukan pelaku kejahatan dapat ditinjau dari beberapa aspek. Aspek pertama, yakni dari pendekatan sifat atau trait theory tentang kepribadian yang menjelaskan bahwa orang yang melakukan pelanggaran hukum adalah orang yang tidak mampu mengontrol emosinya, cenderung berani, dominasi sangat kuat, power yang berlebih, dorongan untuk memenuhi kebutuhan fisik sangat tinggi, dan sebagainya. Aspek kedua, yakni pendekatan psikoanalisis yang menjelaskan bahwa perilaku melanggar hukum merupakan representasi dari id yang tidak terkendalikan oleh ego dan superego. Id ini merupakan impulse (gerakan atau suara hati) yang memiliki prinsip kenikmatan atau pleasure principle. Ketika prinsip itu dikembangkan, superego terlalu lemah untuk mengontrol impulse yang hedonistis. Akibatnya perilaku sekehendak hati asalkan menyenangkan muncul dalam diri seseorang. Dengan demikian salah satu faktor yang mempengaruhi seseorang melakukan pelanggaran hukum dikarenakan memiliki feebleminded atau keterbelakangan otak, meskipun yang bersangkutan tidak menderita penyakit jiwa. Hampir semua penjahat dapat dinyatakan sebagai feebleminded. Di mana orang-orang yang melakukan kejahatan tidak mempunyai kecerdasan yang cukup untuk menaati hukum. ${ }^{13}$

Terlepas dari segala perdebatan yang terjadi dari berbagai perspektif di atas, mengingat daruratnya negara Indonesia akan kejahatan seksual ini, maka untuk saat ini PERPPU No. 1 Tahun yang kini telah disahkan menjadi Undang-Undang No. 17 Tahun 2016 merupakan sebuah solusi yang tepat untuk menangani proses penegakan hukum terhadap tindak pidana oleh pelaku yang melakukan persetubuhan dengan anak (pedofilia) yang tujuannya untuk

\footnotetext{
${ }^{13}$ Abintoro Prakoso, Hukum Dagang dan Psikologi Hukum, LaksBang Grafika, Yogyakarta, 2014, h. 126-130.
} 
memberikan suatu nestapa dalam hukum pidana. Kita tahu beberapa contoh kasus persetubuhan dengan anak (pedofilia) yang terjadi, pada faktanya dapat dibuktikan bahwa pelaku yang melakukan persetubuhan dengan anak (pedofilia) masih banyak mendapatkan vonis pidana penjara yang ringan. Pada praktek penegakan hukum, kenyataannya hakim jarang memutus dengan ancaman pidana maksimal atau bahkan hanya memutus perkara di bawah pidana maksimal dari ketentuan perundangan. Seharusnya pemidanaan yang dijatuhkan untuk pelaku kejahatan pada lembaga pemasyarakatan, pada dasarnya merupakan sebuah alat untuk menegakkan hukum dalam rangka membuat jera pelaku pedofilia atas perbuatan yang telah dilakukan oleh pelaku kejahatan. ${ }^{14}$ Lebih lanjut Barda Nawawi Arief juga menjelaskan bahwa efektivitas pidana penjara dapat ditinjau dari dua aspek pokok tujuan pemidanaan, yaitu aspek perlindungan masyarakat dan aspek perbaikan si pelaku. Dillihat aspek dari perlindungan masyarakat, maka suatu pidana dikatakan efektif apabila pidana itu sejauh mungkin dapat mencegah atau mengurangi kejahatan. Jadi kriteria efektivitas dilihat dari seberapa jauh frekuensi kejahatan dapat ditekan. Dilihat dari aspek perbaikan si pelaku, maka ukuran efektivitas terletak pada aspek pencegahan khusus (special prevention) dari pidana. ${ }^{15}$

Sanksi-sanksi dalam perundang-undangan yang dijatuhkan bagi pelaku kejahatan juga harus didasarkan pada 3 nilai dasar hukum yakni; nilai kepastian, keadilan, dan kemanfaatan. Karena Jika sanksi-sanksi itu tidak didasarkan pada 3 nilai-nilai dasar itu, maka dalam penyelesaian kasus-kasus pelecehan seksual pada anak yang dilakukan oleh pelaku yang melakukan persetubuhan dengan anak (pedofilia) akan sia-sia belaka.

Apalagi jika dikaitkan dari perspektif nilai keadilan dan kepastian, pidana penjara yang vonisnya sangat ringan akan menimbulkan ketidakpastian hukum serta tidak memberikan rasa adil bagi korban yakni anak-anak yang menjadi korban pelecehan seksual yang mengakibatkan trauma fisik dan mental dan juga menghambat anak untuk tumbuh dan berkembang secara optimal. Serta juga dapat menimbulkan kerawanan bahwa anak yang menjadi

\footnotetext{
${ }^{14}$ Dwidja Priyatno, Sistem Pelaksanaan Pidana Penjara di Indonesia, Refika Aditama, Bandung, 2009, h. 71 \& 49.

${ }^{15}$ Ibid., h. 82-83.
}

korban pelaku yang melakukan persetubuhan dengan anak (pedofilia) tersebut, di masa yang akan datang dapat menjadi pedofilia selanjutnya. Menurut perspektif nilai kemanfaatan, pidana penjara masih belum dapat memberikan kegunaan yang baik bagi pelaku yang melakukan persetubuhan dengan anak (pedofilia), karena pidana penjara belum dapat dijadikan tempat untuk melakukan perbaikan atau rehabilitasi untuk merubah sikap, melainkan dapat membuat sikap dari pelaku pedofilia lebih jahat lagi melalui pertemanan dengan pelaku kejahatan lainnya dalam satu sel penjara.

Selama ini ringannya sanksi yang diterima oleh pelaku yang melakukan persetubuhan dengan anak (pedofilia) menimbulkan kesenjangan antara law in book dan law in action dalam praktek penegakan hukum. Seperti contoh kasus pedofilia yang baru saja terjadi di Kabupaten Rejang Lebong, Bengkulu yang menimpa Yuyun, di mana pelaku pencabulan hanya di vonis 10 tahun penjara, serta beberapa kasus pedofilia yang pernah terjadi di Indonesia di masa lalu yakni kasus William Stuart Brown dan kasus William James Vahey mantan seorang guru di Jakarta International School (JIS). Kasus-kasus kejahatan seksual yang terjadi di Indonesia akhirakhir ini juga mengingatkan pendapat yang pernah disampaikan oleh Prof. Dr. Luh Ketut Suryani Sp., $\mathrm{Kj}$., yang menjadi kenyataan dan terbukti. Dalam pendapatnya, Prof. Dr. Luh Ketut Suryani Sp., Kj., menjelaskan bahwa seorang pelaku yang melakukan persetubuhan dengan anak (pedofilia) tidak bisa dicegah dan disembuhkan hanya melalui pidana penjara saja. Ia menambahkan bahwa setelah keluar dari penjara seorang pedofilia tetap akan mengulangi perbuatannya itu yang disebabkan fantasi dan kebutuhan seksual.

Pidana penjara yang seharusnya dapat memberikan efek jera, menjadi tidak bermanfaat bagi pedofilia. Tetapi pidana penjara justru membuat pedofilia semakin brutal dan depresi akibat pidana penjara yang menghalanginya untuk melakukan hubungan seksual kepada anak-anak. Beberapa contoh kasus di atas memberikan kesimpulan bahwa pidana penjara saat ini belum dapat membuat jera pelaku pedofilia, mengingat masih lemahnya sanksi yang diterapkan dalam perundang-undangan dan justru membuka peluang bagi pelaku yang melakukan 
persetubuhan dengan anak (pedofilia) untuk menjadi residivis.

Sehingga dari hal itu sanksi-sanksi dalam perundang-undangan yang dijatuhkan bagi pelaku kejahatan juga harus didasarkan pada 3 nilai dasar hukum yakni; nilai kepastian, keadilan, dan kemanfaatan. Karena Jika sanksi-sanksi itu tidak didasarkan pada 3 nilai-nilai dasar itu, maka dalam penyelesaian kasus-kasus persetubuhan pada anak yang dilakukan oleh pedofilia akan sia-sia belaka. Apalagi jika dikaitkan dari perspektif nilai keadilan dan kepastian, pidana penjara yang vonisnya sangat ringan akan menimbulkan ketidakpastian hukum serta tidak memberikan rasa adil bagi korban yakni anak-anak yang menjadi korban persetubuhan yang mengakibatkan trauma fisik dan mental dan juga menghambat anak untuk tumbuh dan berkembang secara optimal. Serta juga dapat menimbulkan kerawanan bahwa anak yang menjadi korban pedofilia tersebut, di masa yang akan datang dapat menjadi pelaku pedofilia selanjutnya. Menurut perspektif nilai kemanfaatan, pidana penjara masih belum dapat memberikan kegunaan yang baik bagi pelaku pedofilia, karena pidana penjara belum dapat dijadikan tempat untuk melakukan perbaikan atau rehabilitasi untuk merubah sikap, melainkan dapat membuat sikap dari pelaku yang melakukan persetubuhan dengan anak (pedofilia) lebih jahat lagi melalui pertemanan dengan pelaku kejahatan lainnya dalam satu sel penjara.

Tindakan pemerintah melakukan penggantian hukum yang lama atau penerapan hukum baru melalui pembentukan penetapan PERPPU No. 1 Tahun 2016 yang disahkan menjadi Undang-Undang No. 17 Tahun 2016 merupakan keputusan yang tepat dan bijak, mengingat Indonesia saat ini darurat kejahatan seksual dan Pemerintah juga menetapkan kejahatan seksual merupakan kejahatan luar biasa (extra ordinary crime). Sehingga penanganan juga harus dilakukan secara luar biasa. Dan diharapkan beberapa pidana tambahan dan tindakan seperti pengumuman identitas pelaku, pemasangan alat pendeteksi elektronik dan tentunya penerapan kebiri kimia dapat mengefektifkan proses penegakan hukum kejahatan seksual dan dapat memberikan efek jera bagi pelaku yang melakukan persetubuhan dengan anak (pedofilia) dengan menghilangkan gairah seksualnya, serta untuk menjamin perlindungan terhadap anak-anak Indonesia.

Dengan adanya penerapan tindakan kebiri kimia beserta pidana tambahan dan tindakan lainnya, jaminan kepastian hukum dapat diimplementasikan dalam proses penegakan hukum bagi pelaku yang melakukan persetubuhan dengan anak (pedofilia). Karena selama ini sanksi pidana penjara dalam Undang-Undang Perlindungan Anak masih sangat lemah dalam proses penegakan hukum. Kebiri kimia juga telah memberikan jaminan keadilan hukum, khususnya anak-anak dan keluarga yang menjadi korban pelecehan seksual. Kebiri kimia juga memberikan nilai kemanfaatan dalam hukum, kebiri kimia yang diberikan pada pelaku yang melakukan persetubuhan dengan anak (pedofilia) akan memberi kegunaan bagi pelaku pedofilia untuk menghilangkan gairah seksualnya dan sekaligus memberikan terapi dan pengobatan bagi seorang pedofilia. Dan dari perspektif hak asasi manusia, kebiri kimia tidak melanggar HAM, karena reaksi kebiri kimia ini hanya bersifat sementara dan dapat diperpanjang melalui suntikan kimia berdasarkan kordinasi dari pihak-pihak terkait lainnya.

Terlepas dari banyaknya perdebatan yang terjadi terkait penerapan kebiri kimia ini memang masih menjadi polemik di khalayak umum. Tetapi karena urgensi kejahatan seksual yang semakin meningkat di Indonesia ini membuat kebijakan harus segera dikeluarkan untuk menyelamatkan anak-anak yang menjadi korban dari pedofilia ini.

Kebiri kimia yang telah diatur dalam PERPPU No. 1 Tahun 2016 yang kini telah disahkan menjadi Undang-Undang No. 17 Tahun 2016 ini diharapkan dapat menjadi alat dalam proses penegakan hukum kejahatan seksual, mengingat pidana penjara masih sangat lemah dalam implementasi penegakan hukum. Melalui pemanfaatan kebiri kimia dalam bidang medis akan memberikan penguatan pada konsep pemidanaan dalam hukum pidana yang meleburkan pemanfaatan profesi medis ke dalam sistem peradilan pidana di Indonesia.

\section{PENUTUP \\ Kesimpulan}

Pelaku yang melakukan persetubuhan dengan anak (pedofilia) secara umum telah diatur di dalam Pasal 290 angka 2 dan angka 3 KUHP yang 
perbuatannya dibagi menjadi perbuatan persetubuhan dan pencabulan. Serta pengaturan secara khusus telah diatur dalam Pasal 81 dan 82 PERPPU No. 1 Tahun 2016 sebagaimana telah disahkan menjadi Undang-Undang No. 17 Tahun 2016, di mana pelaku yang melakukan persetubuhan dengan anak (pedofilia) dapat di pidana penjara baik secara umum, maupun pidana penjara sebagai bentuk kualifisier seperti pidana mati, pidana seumur hidup, pidana paling singkat 10 tahun dan paling lama 20 tahun serta pidana penjara tambahan sepertiga.

Selain pidana penjara, beberapa tindakan dan pidana tambahan lainnya telah diakomodasi dalam PERPPU No. 1 Tahun 2016 sebagaimana telah disahkan menjadi Undang-Undang No. 17 Tahun 2016 tersebut seperti dapat dikenakan pidana tambahan dan/atau tindakan seperti yang salah satunya adalah kebiri kimiawi untuk menghilangkan sementara nafsu seksual. Mengingat saat ini pidana penjara yang diberlakukan pada Undang-Undang Perlindungan Anak masih sangat lemah dan belum bisa memberikan efek jera, serta masih ringannya vonis yang diberikan oleh Majelis Hakim dalam proses penegakan hukum. Hal itu juga terbukti efektif di Negara Bagian California, Amerika Serikat yang memberlakukan Kebiri Kimia dalam penegakan hukum terhadap pelaku yang melakukan persetubuhan dengan anak (pedofilia).

Sehingga dengan adanya penerapan tindakan kebiri kimiawi ini akan memberikan jaminan kepastian hukum dalam proses penegakan hukum, jaminan keadilan bagi anak-anak dan keluarga yang menjadi korban kejahatan seksual, dan kemanfaatan bagi pelaku yang melakukan persetubuhan dengan anak (pedofilia) sebagai terapi dan pengobatan dalam mengatasi gangguan seksual. Dan dari perspektif HAM bukan merupakan sebuah pelanggaran HAM, mengingat reaksi kebiri kimia yang hanya bersifat sementara. Maka dari itu PERPPU No. 1 Tahun 2016 sebagaimana telah disahkan menjadi Undang-Undang No. 17 Tahun 2016 ini diharapkan dapat menjadi alat dalam proses penegakan hukum kejahatan seksual. Dan meskipun banyak perdebatan antara para ahli di bidang agama, medis, hukum, maupun sosial, tindakan kebiri kimia yang dilakukan semata-mata untuk memberikan jaminan proses penegakan hukum dan perlindungan terhadap anak-anak Indonesia yang rentan menjadi korban pedofilia.

\section{Rekomendasi}

Pertama, Pemerintah harus segera berkordinasi kepada pihak-pihak terkait lainnya (IDI) dalam proses eksekusi pelaksanaan kebiri kimia. Sehingga apabila pihak-pihak terkait (IDI) sebagai eksekutor dapat melaksanakan eksekusi pelaksanaan kebiri kimia, maka pada tataran implementasi nantinya dapat berjalan sesuai dengan regulasi yang berlaku.

Kedua, Pemerintah selain memberikan pidana tambahan dan tindakan juga harus mencari hulu dalam mengatasi kejahatan seksual yang terjadi di Indonesia. Sehingga sanksi pidana bukan merupakan alat satu-satunya yang utama.

\section{DAFTAR PUSTAKA}

\section{Peraturan Perundang-Undangan:}

Undang-Undang Dasar 1945.

Undang-Undang Nomor 1 Tahun 1946 tentang

Peraturan Hukum Pidana (Kitab Undang-undang Hukum Pidana).

Undang-Undang Nomor 23 Tahun 2002 tentang Perlindungan Anak, Lembaran Negara Tahun 2002 Nomor 109, Tambahan Lembaran Negara Nomor 4235.

Undang-Undang Nomor 35 Tahun 2014 tentang Perubahan atas Undang-Undang Nomor 23 Tahun 2002 tentang Perlindungan Anak, Lembaran Negara Tahun 2014 Nomor 297, Tambahan Lembaran Negara Nomor 5606.

Undang-Undang Nomor 17 Tahun 2016 tentang Peraturan Pemerintah Pengganti Undang-Undang Nomor 1 Tahun 2016 tentang Perubahan Kedua atas Undang-Undang Nomor 23 Tahun 2002 tentang Perlindungan Anak Menjadi UndangUndang, Lembaran Negara Tahun 2016 Nomor 237, Tambahan Lembaran Negara Nomor 5946.

Peraturan Pemerintah Pengganti Undang-Undang Nomor 1 Tahun 2016 tentang Perubahan Kedua atas Undang-Undang No. 23 Tahun 2002 tentang Perlindungan Anak, Lembaran Negara Tahun 2016 Nomor 99, Tambahan Lembaran Negara Nomor 5882.

\section{Buku:}

Gultom, Maidin, 2013, Perlindungan Hukum terhadap Anak, Bandung: Refika Aditama. 
Marzuki, Peter Mahmud, 2014, Penelitian Hukum Edisi Revisi, Jakarta: Kencana Prenada Media Group.

Prakoso, Abintoro, 2014, Hukum dan Psikologi Hukum, Yogyakarta: LaksBang Grafika.

Prasetyo, Teguh dan Abdul Halim Barkatullah, 2005, Politik Hukum Pidana, Yogyakarta: Pustaka Pelajar.

Priyatno, Dwidja, 2009, Sistem Pelaksanaan Pidana Penjara di Indonesia, Bandung: Refika Aditama.

Supardi, Sawatri, 2005, Bunga Rampai Kasus Gangguan Psikoseksual, Bandung: Refika Aditama.

Tongat, 2003, Hukum Pidana Materiil, Jakarta: Djambatan.

\section{Jurnal:}

Moog, Audrey, 1999, "California Penal Code Section 645: Legislators Practice Medicine on Child Molesters", Journal Contemporary Health Law \& Policy, Volume 15 Issue 2 Article 13.

\section{Skripsi/Tesis:}

Priyono, Affrik, 2015, "Politik Hukum Pemidanaan Kebiri Kimia Bagi Pelaku Pedofilia”, Skripsi, Fakultas Hukum Universitas Wijaya Kusuma Surabaya, Surabaya.
Wahyuni, Indra Irma, 2011, "Pedofilia Ditinjau Dari Pertanggungjawaban Pidana", Skripsi, Fakultas Hukum Universitas Wijaya Kusuma Surabaya, Surabaya.

Zainuddin, Muhammad, 2007, "Kebijakan Hukum Pidana dalam Rangka Penanggulangan Kejahatan Pedofilia”, Tesis, Fakultas Hukum Universitas Diponegoro, Semarang.

\section{Website:}

NN, Kisah Tragis Balita 2,5 Tahun Korban Kejahatan Seksual di Bogor, https://simomot. com/2016/05/14/kisah-tragis-balita-25-tahunkorban-kejahatan-seksual-di-bogor/, diunduh 6 Juni 2016.

NN, Hukum Kebiri Halal Menurut Islam, http:// poskotanews.com/2016/05/26/hukum-kebirihalal-menurut-islam/, diunduh 20 Juni 2016.

Putro, Hardjo, Yuliardi, Siswi SMP di Bengkulu Dicabuli 14 Pemuda hingga Tewas, http:// regional.liputan6.com/read/2483200/siswi-smpdi-bengkulu-dicabuli-14-pemuda-hingga-tewas, diunduh 6 Juni 2016.

Sasongko, Agung, Bolehkah Hukum Kebiri dalam Syariat Islam?, http://khazanah.republika.co.id/ berita/dunia-islam/islam-nusantara/15/10/30/ nx179u313-bolehkah-hukum-kebiri-dalamsyariat-islam, diunduh 20 Juni 2016. 